\title{
PERSONALITY VALUES' BECOMING IN EDUCATIONAL PROCESS: TECHNOLOGY AND EXPERIENCE
}

\section{Romanyuk L. V.}

\section{INTRODUCTION}

Technology of educational activity of students - future psychologists and managers - is a set of methodological, organizational and methodological guidelines and values that determine selection, composition and sequence of the tools used. It defines the strategy, tactics and techniques of education in the learning process.

A significant factor in the successful application of technology is the need to clarify values of the learning subjects and their re-orientation. The latter are based on the development of personal orientations. Various ways to develop the consciousness of future specialists are suggested by means of the content of psychological and educational impact that sets benchmarks for sense searching activities in logical and intuitive regimes. This content is considered to be the source of pedagogical creativity that is not based on readymade recipes of conduct, but rather on motives for sense creation at large.

In this regard, the main categories of psychological preparation process are the value content, which defines the meaning of education. The outlines of the notion "content" are determined by a "transparent" boundary, which allows personal meanings to its 'territory'. The purpose of psychological and pedagogical training in modern conditions is not just accumulation of knowledge and skills, but a creative approach to their acquisition, i.e., development in the course of studying psychological and educational disciplines. Since its modern meaning is multi-component, it should include not only knowledge but also ways of practical activities, creative experience, and personal values. This particular approach is able to provide quality education to meet modern requirements faced by each person in the rapidly changing society.

According to the leading educators and psychologists, one of the teacher's important tasks is to influence spiritual and mental development 
of students and their values, project the socio-cultural environment, build a psychological and pedagogical environment for normal human development at key stages of ontogenesis ${ }^{1}$ (V.A. Bolotov, V.I. Slobodchikov, 1997), i.e. creative problem solving skills are realized and self-realization is developed. These special intellectual skills enable to perceive common things in new ways, to "re-discover" a complex world of psychological and educational relations. Their individual comprehension is extremely difficult and relying on somebody else's suggestions means blocking of independence. However, there is a methodology that does not assert, does not give instructions, but encourages a thoughtful, critical insight to discover hidden causes of phenomena, or in other words, to start self-organization of the important component of psychological and managerial work, to the sense seeking activity. One of the efficient ways of humane cognitive consciousness is suggested by phenomenological psychology and pedagogy ensuring reaching deep inside into what is really human in a human being.

Phenomenological pedagogy is clearly elucidated by E. Husserl through his method of eidetic reduction. This method determines the path to the natural orientation of a person's relation with all people, with the humanity through "clearing" of consciousness filled with prejudices of "social" ideologies that divert people from their creative mission tempting them with "dissolution in public consciousness"2 (Husserl E., 1911). The overall method of eidetic reduction consists in return to one's natural human nature - and namely, to the microcosm that is represented by specific experience. Through communication with the macrocosm of human community the latter gives rise to personal human values, concepts and experiences transforming the world into a personal world phenomenon. This transformation occurs in experiences of the consciousness that create meaning and define its existence in interconnected natural phenomena. The technological design potential of high structures of a personality appears to be in the introduction of the problematic thinking. Aporetic (a problem-thinking level) creates a precondition for transition to theoretical thinking, which allows to understand the meaning and content of human values and ways of implementing them in life, thus developing consciousness. The term

\footnotetext{
${ }^{1}$ Bolotov V.A, Slobodchykov V.I. Development of Professional Pedagogical Education / Pedagogy. 1997. - № 4. - P. 66-68.

${ }^{2}$ Husserl E. Philosophy, as Strict Science. - M.: Logos, 1911, vol. 1.
} 
"personality value" indicates inclusion of consciousness not by force, but in a choice-related situation ${ }^{3}$ (Hartmann N. Ethics. - M., 1958, 11, 862).

Pillars of such cognition and self-creation are values that correspond to the subjective moral experience of an individual.

There are various psychological interpretations of values, depending on conceptual affiliations of authors. In particular, S. Freud's psychoanalysis, showing a person as enslaved by unconscious inclinations and desires, emphasizes that the Super-Ego is the highest value in the form of prohibitions and restrictions as to the manifestations of these inclinations and desires and can become hostile to an individual and stifle his productive values. And only when a compromise is reached between Id and a carrier of higher values channeling the energy of libido and instincts toward useful and productive actions, individual's values become distinctive and constructive. The Austrian psychoanalyst A. Adler rejected his predecessor's concept and argued that availability of individual values can not be achieved through a compromise between a person's unconscious and a carrier of higher values through redirection of the energy of this complex into the mainstream of productive activities. It is achieved through the innate ability that is revealed in an individual human life. Adler called this ability a social sentiment or a social interest.

A Ukrainian scientist V. Romenets ${ }^{4}$ deducts values from the structure of life. The most significant ones include values related to moral and meaning. Human values, he believes, are the first and foremost values of mutual understanding, mutual cognition and interaction (Romenets V.A., Manoha I.P., 1998).

A Russian researcher B. Parygin ${ }^{5}$ singles out value orientations as values of the society, that are to some extent acquired by individuals, as well as symbols as means of consolidation of the sanctioned system of values. They "... combine rational sense... of social values with a high emotional level and poignancy of their perception and experiences" (Parygin B.D, 1971). They are a part of the structure of the social-specific experience. He combines the above parameters into the notion of "value".

\footnotetext{
${ }^{3}$ Hartmann N. Ethics. - M., 1958.

4 Romenets V.A. Manokha I.P. History of Psychology of the Twentieth Century / Introduction by V.A. Tatenko, T.N. Titarenko. - K.: Lybid, 1998. - 992 pp.

${ }^{5}$ Parygin B.D. Fundamentals of Socio-Psychological Theory. - M: Thought, 1971.
} 
V. Yadov ${ }^{6}$ examines four levels of disposition of social attitudes in the hierarchical structure (Yadov V.A, 1975). The fourth (top) level system of values is occupied by a person's system of values, which he believes to be a dispositional hierarchy as value orientations for the purpose of life activities and means of their implementation.

In his writings D. Usnadze ${ }^{7}$ examines the phenomenon of objectification which can be attributed to psychological mechanisms of settings and values. He calls objectification a specific act which transforms the subject or phenomenon into the special objects of observation on the basis of human activity. It transforms the existing objects into subjects on which a person concentrates and objectifies them. According to him (Usnadze D.N., 1969), objectification is the result of transition of the external into the internal, from subject to object, creation of an object, with which a person interacts. The act of attention plays a significant role. It separates the object from the circle of primary perceptions based on orientations. The psychic level of objectification is inherent to people. They are capable of thinking and building foundations of cultural life and acting as creators of cultural values.

Thus, the basic idea of the system of orientations and values is that these phenomena are the result of activity of individual feelings, knowledge and behavioral reactions associated with this object. They represent value inclinations to a certain object, and their system consists of five components: orientation, cognitions (beliefs and knowledge), affective responses (feelings), behavioral intentions (intents), and behavior per se. Immediate changes in behavior patterns and verbal techniques trigger a chain reaction mechanism that changes orientations and values.

Becoming of values is their occurrence, formation in the process of person's development. They are often accepted from the environment or constitute an opposite value that proceeds from environment to a person, when the person refuses to identify himself with family values or culture values. When studying the process of becoming an adult, it is important to focus on understanding the terms "becoming" and "developing". As is known, in the domestic literature of the last century the concept of "becoming" was used in the context of the concept of "development" and is usually identified with the latter. At the same time, modern

\footnotetext{
${ }^{6}$ Yadov V.A. On Dispositional Regulation of Social Behavior of Individual // methodological problems of social psychology M.: Nauka 1975. - Pp. 89-105.

${ }^{7}$ Usnadze D.N. Psychological Research. - M.: Nauka, 1969. - 213 p.
} 
psychological science offers a terminology in which a large thesaurus of concepts in the category of "development", among which the leading place is the term becoming. Author ${ }^{8}$ (L. Romanyuk, 2014) substantiate the essence and correlation of these concepts. The latter refers to the spontaneous variability of things and phenomena, their continuous transition (transgression), transformation into others. This concept appears as the "first truth" (G. Hegel). Thus, becoming is the transition of opportunity into reality in the development process. Its main feature is that the existence of the phenomenon has already begun, but has not yet taken shape. It acts as a process of originating opportunities and turning one into reality. Proceeding from this, the becoming of personality values means a continuous transition, the transformation of those values that acquire in the mind of an young adult person of a meaningful level and continue to integrate into its value system at the level of consciousness. At the same time, values are reconstructed, gaining significance for the human being, hierarchized, embracing new meanings and structured in new ways human living spaces.

Despite numerous studies of nature and mechanisms of values and mechanisms as interdisciplinary problems in psychology there are practically no studies of psychological bases of becoming of values and sense of unity of their content and dynamic representations in higher education. There were particularly thorough studies of values of humanities students as future professionals, teachers, professors, and athletes. However, studies of the becoming of values and meaning (sense) involving students of economy, agriculture, technical and psychological professions were not conducted in universities.

The author's continuous work in schools of business and finance, agricultural technologies, mechanization and electrification, department of biotechnology and veterinary medicine, and the department of psychology and social rehabilitation has identified the specific interest and identified the problem of the current research.

The purpose of this paper is an attempt to uncover ways and mechanisms of becoming of values of students of the departments of accounting and auditing, management of organizations, and psychology.

\footnotetext{
${ }^{8}$ Romanyuk L.V. Psychology of personality values' becoming. Manuscript. The thesis for obtaining of the Doctor's degree in psychological science, specialty 19.00.07. - Educational and Developmental Psychology. Taras Shevchenko National University of Kyiv, Kyiv, 2014. - P. 57-70.

${ }^{9}$ Hegel H.V.F. Philosophy of History / / Works - M.-L., 1935. - T. 8. - P. 8-132.
} 


\section{Development of the Workshop}

In this study, the author used methods of psychological training in the process of influence on students' values development. It incorporated methods and techniques of neuro-linguistic programming (NLP).

The program was to create conditions for changing language strategies of students. Ideally, it is facilitating of the transition of negative values to positive ones, making possible the valuable reorientation of consciousness and behavior. But the mechanism of transition is quite complicated. Therefore, we introduced the future psychologists, accountants, and managers to the common basics of values becoming techniques. It was designed as the human variant of neuro-linguistic programming (NLP) of R. Bendler ${ }^{10}$ and J. Grunder using elements of non-violent communication of the M. Rosenberg and the practical psychology course of 40 NLP training exercises by R. Johnson ${ }^{11}$ (R. Johnson, 2001). Unlike NLP programs that are targeted at fast changes of individuals with mental difficulties and violations, the proposed technique is not designated to influence through unconscious, but to gradually (rather slowly) develop the meaningful awareness of personal values. The program is designed as follows.

Each student had to master two kinds of knowledge about oneself: knowledge-description and knowledge as control of one's activities. The former is the result of applying diagnostics, which allows to obtain a wide range of knowledge of the student's identity. Obtaining such knowledge about oneself allows to compare oneself with others, to formulate questions aimed at further self-discovery, explanation of certain facts of one's own behavior.

Another type of knowledge is acquired by analyzing the activities that students manage. During this analysis, hidden mental constructions that govern behavior are understood. Acquiring this knowledge (selfawareness) helps to purposefully adjust the student's understanding of the world and change behavior without external influences. In fact, this is selfcontrol taught to students through pedagogical support.

NLP is a modeling process and a toolset to intensify the psychological mechanisms of development and change. It is believed that it helps achieve resource condition, which seems to allow to achieve the necessary results. NLP allows to influence the state, opening up new behavior patterns. It is

\footnotetext{
${ }^{10}$ Bendler R. Magic in actions. Meta Publications,U.S.; New edition (1 Jun. 1992). 228 p.

${ }^{11}$ Johnson R. 1940 NLP Training Exercises. Moscow: Publishing "+ PCB, 2001. 384 pp.
} 
defined as "a set of techniques, models and strategies that help successful communication, growth, personality changes and learning"12 (Revell J., Norman S., 1997, p. 14). NLP techniques are intended to set up a rapport (the central concept of this technique), that creates harmonious relations between the participants of communication and interaction of such relations that allow to program the most favorable responses to speech or actions by participants of communication, this interaction provides complete understanding and mutual empathy and helps avoid or quickly correct any adverse situation and avoid misunderstanding in communication.

It is used in teaching as a means of establishing contact between teachers and students, i.e. as a means of harmonizing relationships, goals, intentions, ideas, opinions of all the participants in the learning process. Such harmonization provides for convergence of their emotional perception of reality and learning to respond to this reality, offering a psychological climate for optimal learning and obtaining the best results. With the help of NLP techniques the teacher influences the nonspecific psychic reactivity of those who learn by creating a favorable psychological climate and using nonspecific factors in the classroom behavior and communication - voice, intonation, certain ways of submitting ideas, suggestions etc. This is perhaps the most valuable characteristic of the NLP method, which makes it so effective for training, including the study of psychology.

Four exercises have been designed to clarify the hierarchy of values and their impact on the development for the practical courses. The exercises are suited to different learning styles. In the beginning, a teacher introduces the principles through handouts and demonstrates skills for the participant to see and hear even before they practice them. Most of the exercises were done in groups of three students. The third participant in the group was usually a facilitator. He oversees the progress of the group, and directly supports the participants and supervises exercises. Observation constitutes an essential part of learning and helps develop observation and hearing skills.

Our task was limited to control of each group; intervention was made when a group veered off the set course. This is easily achieved if all the groups which perform the exercise are working in one room provided there

\footnotetext{
${ }^{12}$ Revell J., Norman S. In Your Hands. NLP in ELT. - London: Saffire Press, 1997. - 144 p.
} 
is enough space not to interfere with each other. It is recommended that small group do exercises without using tables.

A wrap-up discussion takes place following practical training to facilitate reflection. Under certain conditions, a certain time for self reflection was also found useful. Observation of demonstrations, doing exercises and reviews in the form of discussion gives more variety to the methods of value formation. The first exercise allows to clarify the participants' hierarchy of values, and the second one reveals their orientations and values, and the third one aims to form the ability to use personal values in business relations or problem solving situations, and the fourth one facilitates recognition of other people's values.

The purpose of training is announced in the introduction, i.e. what the student participants can achieve by doing exercises, and the necessary resources are provided.

The basic principles underlying the lessons are supported by examples the teacher uses in his/her presentation and a detailed plan of exercises. Teaching method support of the exercise provides for review questions asked during the review discussion.

Values in the three spheres of human activity are developed in the course of research 1) communication within the inner circle (family, friends), 2 business (professional), 3) one's own self (emotions, feelings).

During the first stage of training the aim is to provide teaching support for students in identifying values and use them to control themselves and others, encouraging others and themselves to act; the students are challenged to learn and help others to learn to formulate purposes taking into account the most significant things of an individual, i.e. basic values.

An interview method was useful in finding correspondence between studying, future work, objectives, and relationships with others or a situation on one hand, and student's values on the other.

Motivation was to clarify the students' preferences in their personal life, studying, future job or career, and use of this information to encourage oneself to action.

The groups could choose the type work: whether it concerned communication and relations within the inner circle (family, friends), activity (professional), imaginary future self (I-concept), or leisure activities. The exercise contained questions about what would force them to leave any situation. Sometimes the students experienced discomfort 
when discussing such situations. But the researcher stressed that the real and important topics were raised in order to allow students to explore the values important to them. Since the question, what can result in a decision to change a job or terminate relations, allows to reveal oneself and understand others. All of this makes the NLP method adapted by the author to the student audience and the current times.

Each student had an opportunity to answer the following questions: What was the correlation of the students' values? What was similar and what was different? How can these values influence person's choice? How could this knowledge help influence, motivate and manage? As a result of the first exercises, a hierarchy of values was built for the above mentioned three areas of students' activities. To better adapt the NLP method to our student audience, self-assessment methodology was added to the handouts enabling the students to manifest values of higher and lower levels.

The purpose of the second stage was to teach participants to use questions that can discover and discuss the values underlying human actions and aspirations, in particular, to build a bridge between what's important for him/her and organizations which he /she would manage. Exercises at this stage were limited to identification of their values. Interviews revealed what satisfaction students seek to find in the learning process and future activities. The discussions were directed at identifying the values that underlie the partner's positions for each one to explore alternative ways of achieving them.

This method of the exercises aimed to familiarize the participants with the questions which help identify values. In particular this one: "What is important for you in...?"; "What should motivate you...?"; "What makes you...?"; "What forces you...?" The necessity of clarifying the meaning of values by means of questions and hints was stressed. For instance: "What exactly do you mean by...?", or "What exactly would you do... in this situation?". For example, both partners, whose role was played by the students, appreciated honesty. And yet between them there was an argument because one of them considers wages to be fair if they meet needs, while the other believes that payment should be relevant to the effort made. Analyzing the concept of "justice", the students formulated questions to clarify each of the participants' viewpoints. A wrap-up discussion helped to clarify certain changes in the minds of the participating students which took place in the process of activization of the above said psychological mechanisms. 
Similar to the first stage of the experiment, each participant had an opportunity to present to the audience his/her answer to the question: What values were disclosed? What was the difference in the meanings ascribed by various participants to the same values? To what extent did the students' values correspond to their perceptions and how could they achieve greater compliance?

Changes have been traced through the method of value orientation (D. Leontyev, 1992) adapted by us to our student audience ${ }^{13}$.

The purpose of the third exercise was to teach participants to listen to both sides during a dispute, to identify a collision of values, to help the parties clarify the cause of this collision and, if possible, find compromise solutions of the problems.

At this stage the participants were acquainted with the basics of conflict management by clarifying their personal values, and the students came to realize that conflicts arise mainly because of the inconsistencies between orientations and values. For example, if a person is focused on the end result and pays attention to the minutest detail, then he finds it difficult to work with a colleague who focuses on creativity, generates new projects, and skips details. The problem is almost impossible to solve during negotiations without intermediary questions that lead to convergence of values through harmonization of denotations and connotations. As a result, both sides from the above example (let's call one of them 'pedantic', and the other 'proactive') agree with the following: before the "proactive person's" project starts, the "pedant" advises to adopt a plan that will provide for another meeting to resolve all minor issues, before the "pedant's" project starts the "proactive person" helps, offering new ideas. At the end they usually agree on the time needed to try a new style of collaboration.

The fourth exercise was designed to teach participants to recognize values of others based on their nonverbal behavior. At the beginning of this exercise the participants were acquainted with the basics of selection of clues for values of other people. It was specifically admitted that sometimes students may skip talking about the values that influence their behavior, but their non-verbal response is the major clue to their attitude to what is valued by others. The relationship between value orientation and nonverbal behavior is revealed through a number of examples of

\footnotetext{
${ }^{13}$ Leontyev D.A. Methods of Studying Value Orientations. - M.: Meaning, 1992. - 64 pp.
} 
management practices and knowledge of "Psychology of Communication" and "Determination of a Personality Type" test. Students made notes of the identified non-verbal reactions.

The review was aimed to activate the reflection mechanism of the students participating in the class, and it consisted in their answers to the following questions: How many participants were able to successfully implement an imaginary object? What helped them succeed? What interested them most in the values of their peers? How could they apply this idea to influence their peers? Thus, one was able to specify a hierarchy of values of the students- participants, disclose and discuss the values that underlie their human aspirations and actions, identify causes of the collision of values and, whenever possible, find mutually acceptable solutions to problems, train the participants in identifying the participants' values based on their nonverbal reactions.

\section{Method, Results, Discussion and Conclusion \\ Method}

During the research of the psychological mechanisms of students' value becoming, it was established how the experiment impacts specific changes in the ranking of values resulting from the NLP training technology.

To detect the changes in the values of students during training sessions, multivariate disperse analysis was conducted. It's purpose was to check the hypothesis regarding the significance of the main effects of the factors and their statistical interdependence. A dependent variable was the rank of values as suggested by M. Rokeach ${ }^{14,15,16}$ (V.A. Yadov, 1979; Rokeach M., 1972; Rokeach M., 1973). The Institute (major) and gender were the independent variables (factors) in our experiment; dependent variable being the psychological impact on the development of the students' values. The specificity of the latter factor, compared with the former, is that a change of the dependent variable was analyzed for the same students before and after the exposure. Since this factor is "intrapersonal", in this case we deal with the interconnected student samples.

\footnotetext{
${ }^{14}$ Selfrealization and Prediction of Individual's Social Behavior / ed. V.A. Yadov. - L.: Nauka. Leningrad Branch, 1979. - 264 pp.

${ }^{15}$ Rokeach M. Beliefs, Attitudes and Values. - San Francisco: Josey-Bass Co, 1972. - 214 p.

${ }^{16}$ Rokeach M. The nature of human values. - New York : Free Press, 1973.
} 
The variance analysis allows us to break the dependent variable into components, each of which is influenced by a level of the relevant factors, independent action, or rather, by a joint action of several factors.

Thus, several variables were used to test the working hypotheses concerning differences in average ranking of values: 1) for students of various departments; 2) between male and female groups of students; 3) students representing different genders and departments; 4) between the first testing of values during the pilot study and the second - following the training. The author also checked the hypothesis as to the effects of training on the changes in average ranking of values with reference to students' majors (department); gender; gender and department combination was also tested.

Each of the hypotheses listed above was based on the assumption that there were no significant differences in the changes of the dependent variable under the influence of independent variables (factors). In other words, zero hypothesis was taken as a basis. If the F-criterion associated with each hypothesis turned out to be high enough for the probability of its random appearance in accordance with just zero hypothesis to be low enough $(\alpha<0,05)$, then the null hypothesis was rejected and its opposite (alternative) was accepted, which claims that some averages are not equal to each other. The conclusion that some differences led to rejection of the null hypothesis was made on the basis of the analysis of the tables of average values of dependent variables and statistical graphs of interdependence of factors. When interpreting the results of the factor analysis, only the significant figures were taken into account with $p<0,05$. The criterion for assessment of the impact on the attributes (values) of the factors regulated in the experiment was Fisher's F-criterion, i.e. criterion for assessment of the impact of symptom factors regulated in the experiment ${ }^{17}$ (Burlachuk L.F., Morozov S.M, 1989 , p. 48). In our interpretation, we proceeded from the highest meaningful value $(\mathrm{p}<0,05)$ of the F-ratio to the lowest meaningful value.

\footnotetext{
${ }^{17}$ Бурлачук Л.Ф. Словарь-справочник по психодиагностике / Л.Ф. Бурлачук. С.М. Морозов - Киев : Наукова думка, 1989, p. 48.
} 


\section{Results}

In particular, the highest F-ratio $(F=13,085$ at $p=0,001)$ in the study was scored by "Erudition" of the I-values which changed under the direct influence of the training irrespective of the gender and specialty (faculty, institute) factors. The latter two indicated the trends of changes that occurred under the influence of the former (Table 1.).

According to the gender factor we received the average ranking for male students after training $\mathrm{M}=4,85$, with $\mathrm{m}=0,63$ (before training $M=9.79$, with $m=0,75)$, and for female students the average rank $M=6$, 51 , with $\mathrm{m}=0,80$ (before training $\mathrm{M}=10.70$, with $\mathrm{m}=0,95$ ).

According to the specialty (faculty, institute) factor we obtained the following results of the change of orientation towards development: male students majoring in business management changed their orientation in relation to education and development in the course of comprehension and influence of the researcher from average ranking $M=9,29(\mathrm{~m}=1,76)$ to $-M=6,29(\mathrm{~m}=1,48)$, (difference $M=6)$, and female students in this area of education - from $M=10,70(\mathrm{~m}=1,47)$ to $-\mathrm{M}=6,20(\mathrm{~m}=1.24)$ (the difference being $M=4,50$ ). Students majoring in audit and accounting changed their attitude in favor of the need to develop work constantly to improve physically and mentally from the mean rank $M=9,43(\mathrm{~m}=1,25)$ to $-M=5,29(m=1.05)$ (difference $M=4,14)$, students of psychology from $M=8,20(\mathrm{~m}=2,08)$ to $-\mathrm{M}=4,80(\mathrm{~m}=1,75)$, (the difference being $M=3,4)$. Another significant change in the rank of values due to the training impact was T-value "Empathy" $\mathrm{F}=13,364$ at $\mathrm{p}=0.000$. Differential effects by gender were manifest in $M=9,33$ (at $\mathrm{m}=0,76$ ) prior to the researcher's influence and $\mathrm{M}=6.20$ (at $\mathrm{m}=0,70)$ following it male students $(\mathrm{M}$ difference $=3.13$ ) and $\mathrm{M}=11.14$ (when $\mathrm{m}=0,95)-$ prior to the training and $\mathrm{M}=6.56$ (at $\mathrm{m}=0,88$ ) - following it for female students $(M$ difference $=4.58)$.

For T-values significant changes of values' rank during trening's experimental impact was T-value "Cognition" $\mathrm{F}=31,125$ at $\mathrm{p}=0,000$. Differential gender effects were manifested in $\mathrm{M}=9.33$ (at $\mathrm{m}=0.76$ ) before the effect of training and $M=6.20$ (at $\mathrm{m}=0.70$ ) after it in male students (difference $\mathrm{M}=3.13$ ), and $\mathrm{M}=11.14$ (at $\mathrm{m}=0.95$ ) - before training and $\mathrm{M}=6.56$ (at $\mathrm{m}=0.88$ ) - after it in female students (difference $\mathrm{M}=4.58)$. 
Table 1

Direction of changes of values-means in different student groups formed by combinations of department and gender and intrapersonal factors of a researcher's influence

\begin{tabular}{|c|c|c|c|c|c|c|c|c|}
\hline \multirow{3}{*}{ I-values } & \multicolumn{8}{|c|}{$\begin{array}{c}\text { Intrapersonal Influence } \\
\text { Within-Subjects Contrasts }\end{array}$} \\
\hline & \multicolumn{2}{|c|}{$\begin{array}{c}\text { influence } \\
\mathrm{V}\end{array}$} & \multicolumn{2}{|c|}{$\begin{array}{l}\text { influence } \\
\mathrm{V}\end{array}$} & \multicolumn{2}{|c|}{$\begin{array}{c}\text { influence } \\
\mathrm{V}\end{array}$} & \multicolumn{2}{|c|}{$\begin{array}{l}\text { influence } \\
\mathrm{V}\end{array}$} \\
\hline & $\mathrm{F}$ & Sig $p$ & $\mathrm{~F}$ & Sig $p$ & $\mathrm{~F}$ & Sig $p$ & $\mathrm{~F}$ & Sig $\mathrm{p}$ \\
\hline $\begin{array}{l}\text { Neatness } \\
\text { (cleanliness) v19 }\end{array}$ &, 001 & ,969 & ,961 &, 458 & 5,416 & ,023 & 2,016 &, 102 \\
\hline $\begin{array}{l}\text { Good manners } \\
\text { v20 }\end{array}$ & ,842 & ,362 & 1,782 &, 115 & ,078 &, 781 & ,557 & ,695 \\
\hline $\begin{array}{l}\text { High } \\
\text { aspirations v21 }\end{array}$ & 9,680 & ,003 & 1,494 & ,193 & ,984 & ,325 & ,287 & ,885 \\
\hline Cheerfulness v22 & 8,972 & ,004 & 1,605 &, 159 & 10,57 & ,002 & 1,689 &, 162 \\
\hline Diligence v23 & 1,383 & ,244 & 1,748 &, 123 & ,252 & ,617 &, 250 & ,909 \\
\hline Independence v24 & 4,642 & 035 & 2,427 &, 034 & ,089 &, 767 & ,434 &, 783 \\
\hline $\begin{array}{l}\text { Intolerance to } \\
\text { faults v25 }\end{array}$ & ,673 & ,415 & ,815 & ,562 & ,007 & ,934 & ,442 &, 778 \\
\hline Education v26 & $\begin{array}{c}13,08 \\
5\end{array}$ & ,001 & 2,629 & ,023 & 087 &, 769 & 1,747 &, 149 \\
\hline $\begin{array}{l}\text { Responsibility } \\
\text { v27 }\end{array}$ &, 054 & ,817 & 1,888 & ,095 & ,300 & ,586 & ,898 &, 470 \\
\hline Rationalism v28 & 1,820 &, 182 & 1,775 &, 117 & ,399 &, 530 & 1,093 &, 367 \\
\hline Self-control 29 & ,086 &, 770 & 2,313 & ,043 & 5,919 & ,018 & 4,961 & ,001 \\
\hline $\begin{array}{l}\text { Courage in } \\
\text { defending one's } \\
\text { point } v 30\end{array}$ & 4,794 & ,032 & 4,316 &, 001 & 1,952 &, 167 & 4,502 & ,003 \\
\hline Strong will v31 & 2,663 & ,107 & ,493 & 811 & 3,820 &, 055 & 4,198 & ,004 \\
\hline Tolerance v32 & 7,011 & ,010 & 3,664 &, 003 & 7,781 & ,007 & 2,838 & ,031 \\
\hline Honesty v33 & 2,187 &, 144 & 1,338 &, 252 & 1,565 &, 215 &, 438 &, 781 \\
\hline Sensibility v34 & $\begin{array}{c}13,36 \\
4\end{array}$ & ,000 & 1,250 & ,292 & ,053 & ,819 & ,338 &, 851 \\
\hline $\begin{array}{l}\text { Width } \\
\text { of views v35 }\end{array}$ & ,321 &, 573 & ,326 & ,921 & ,191 & ,663 & 1,356 &, 258 \\
\hline $\begin{array}{l}\text { Good } \\
\text { performance v36 }\end{array}$ & 3,926 &, 051 & ,592 & ,736 & 2,338 &, 131 & ,764 &, 552 \\
\hline
\end{tabular}




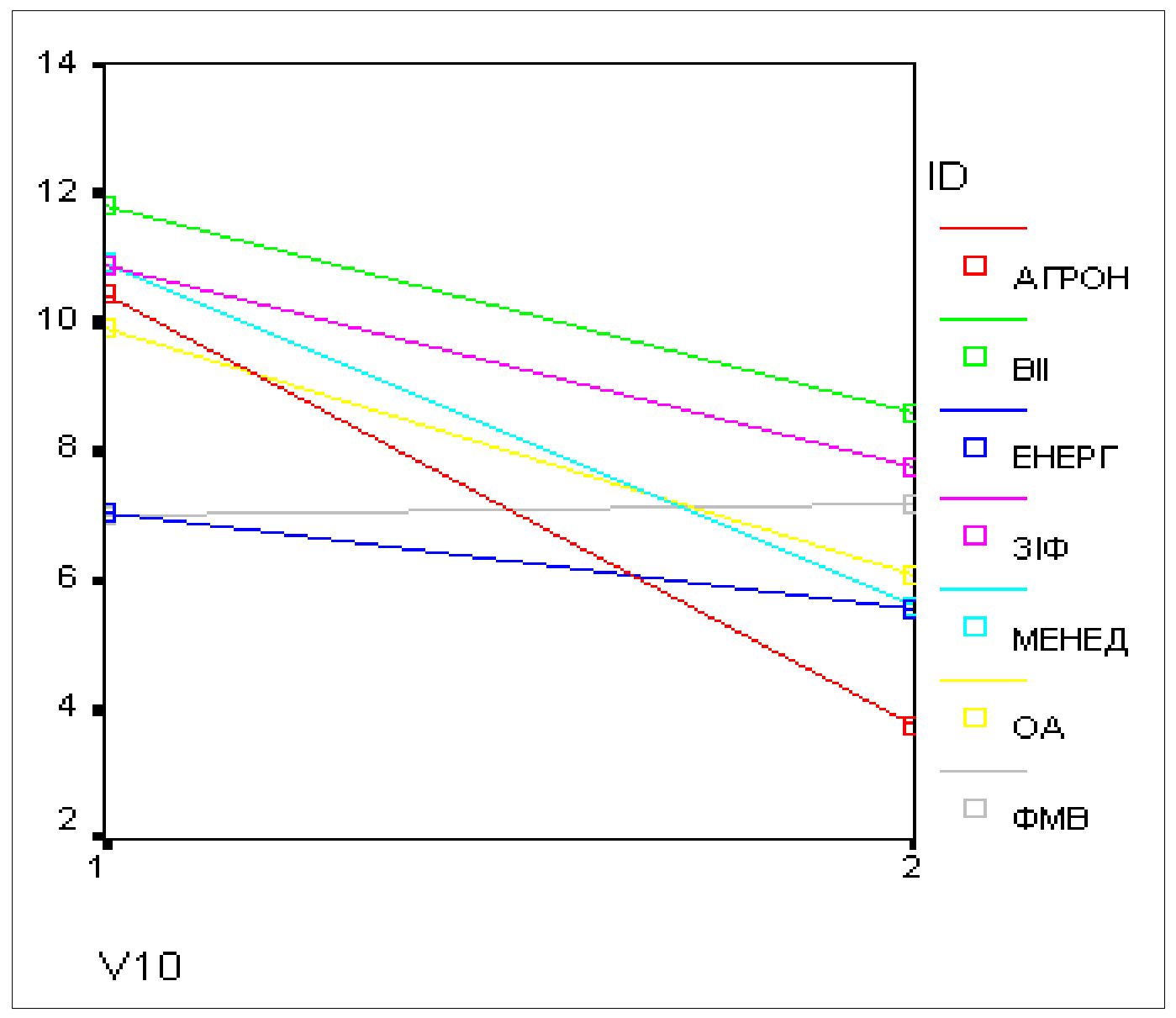

Fig. 1. Differential effects of changing the rank of the T-value "Cognition" in the process of training for faculty factor

The differential effects of changing the rank of the T-value "Cognition" in the course of training in a specialty (faculty, institute) can be observed in Fig. 1. The directions of significant changes in the ranks of the T-value "Cognition" in students of different faculties, whose representatives participated in the developmental experiment, are traced here. In particular, students in the specialty "Management of Organizations" significantly changed their attitude to the value of "Cognition" from the average rank $\mathrm{M}=10.00(\mathrm{~m}=1.77)$ to $-\mathrm{M}=4.57$ $(\mathrm{m}=1.64)$, (difference $\mathrm{M}=5.43$ ), and female students - from $\mathrm{M}=11.60$ $(\mathrm{m}=1.49)$ to $-\mathrm{M}=6.30(\mathrm{~m}=1.37)$, (difference $\mathrm{M}=5.30)$; students in the specialty "Accounting and Auditing" - from $\mathrm{M}=9,67(\mathrm{~m}=2,70)$ to $M=7,00(\mathrm{~m}=2,50)$, (difference $\mathrm{M}=1,67)$ and female students - from $\mathrm{M}=10.00 \quad(\mathrm{~m}=1.77)$ to $\mathrm{M}=5.71 \quad(\mathrm{~m}=1.64)$, (difference $\mathrm{M}=4.29)$; students of the Institute of Agrotechnology - from $M=8,86(\mathrm{~m}=1,77)$ 
to $-\mathrm{M}=3,43(\mathrm{~m}=1,64)$, (difference $\mathrm{M}=5,43)$ and female students from $M=16,00(\mathrm{~m}=3.31)$ to $\mathrm{M}=5.00(\mathrm{~m}=3.07)$, (difference $=11.00)$; students of the Faculty of Veterinary Medicine - from $\mathrm{M}=8,43(\mathrm{~m}=1,77)$ to $-M=8,71(m=1,64)$, (difference $M=-0,28)$ and female students from $M=6,09(m=1.41)$ to $M=6.18(m=1.31)$, (difference $M=-0.09$ ); students of the Zoo Engineering Faculty - from $M=9.50(\mathrm{~m}=2.34)$ to $\mathrm{M}=5.50(\mathrm{~m}=2.17)$, (difference $\mathrm{M}=4.00)$ and female students - from $\mathrm{M}=12.00(\mathrm{~m}=2.09)$ to $\mathrm{M}=9.60(\mathrm{~m}=1.94)$, (difference $=2.40)$.

Students of the specialty "Energy in agricultural production" of the Institute of Mechanization and Electrification change their attitude in favor of the need to know (constantly work on themselves, expanding their education, outlook, general culture, intellectual development) from the middle rank $\mathrm{M}=7.07(\mathrm{~m}=1,25)$ to $-\mathrm{M}=5.57(\mathrm{~m}=1.16)$ (difference $\mathrm{M}=1.50)$ and cadets of the Military Engineering Institute - from $\mathrm{M}=11.80(\mathrm{~m}=2.09)$ to $-\mathrm{M}=8,60(\mathrm{~m}=1.94)$, (difference $\mathrm{M}=3.20)$.

A detailed analysis indicates significant changes in the orientation to development and cognition in the training process (the difference between grades before and after training ranges from 3-5).

As a result of participating in a developmental experiment, there was an increase in developmental orientation and cognition with some differences in the middle ranks, which depended on the interaction between the gender and the faculty where the student studied. Thus, students in the specialty "Organization Management" rank T-value "Development" has moved up 6 ranks, and in students - by 4,50; students in the specialty "Accounting and Auditing" changed their attitude towards it within 8 ranks above, and female students - respectively 4,29; students of the Institute of Agrotechnology also have an increase in the rank of this value by 8.85 , and in students - by 8.5 units; students of the Faculty of Animal Engineering make the choice in favor of development in the process of training and the difference is -6.50 , and the students of this faculty - 2.20; among the students of the Faculty of Veterinary Medicine the difference between the ranks is the lowest - 0.71, and in the students 1.46; at students of institute of mechanization and electrification - 4.14; cadets of the Military Engineering Institute - 3.4.

Thus, there is a significant increase in the rank of T-values "Development" and "Cognition" in students of all specialties, faculties and institutes who voluntarily participated in the developmental experiment 
and observed some differential effects resulting from the interaction of independent factors of gender and faculties.

The multivariate analysis of variance shows that in the course of the training there were significant changes in students' values, and practically all working hypotheses were confirmed.

\section{CONCLUSIONS}

In the process of training, intra-personal and socio-psychological mechanisms of values' becoming significantly intensified; especially interest, self assessment, and reflection. Multivariate analysis of variance was conducted to actually confirms all the working hypotheses and conclude that introduction of training preparation into the educational process enhances the influence of socio-psychological mechanisms and promotes activation of the intrapersonal mechanisms of value development of students (10 indicators of changes in average rank T-values and eight indicators of I-values proved to be reliable). Virtual increase in the rank of T-values "Development " and "Cognition" was observed in all the students who volunteered for the experiment and certain variable effects arising from the interaction of independent factors of gender and major were observed. Significant changes that took place in the students' values among the values of "Development" and "Cognition", and among values-means of "Education" and "Sensibility" result from the fact that during training these values were the most specified to meet the requirements of the training subject.

The use of methods developed by M. Rosenberg and R. Bendler, J.Grunder allowed the subjects of the educational process to change to a better relationship style, introduce a powerful element of self-control into these relationships. Having mastered a particular language, one not only begins to speak in a different way, he starts to see events in a different light, or to understand and respond differently (even internally!). Thus, a change of language and learning strategies, as well as self-control orientation activate one's psychological mechanisms of values, when construction of changes in the style of communication is a change in consciousness and behavior patterns and values help the subject of the educational process to develop understanding of the phenomena and ability to develop the spiritual side of one's personality.

Our future researches on development of students' values include investigation of interaction and mutual influence of intra-personal and sociopsychological mechanisms on their development, which is highly important for practical management, training technology and education of students. 


\section{SUMMARY}

The paper describes ways, mechanisms and their effects in the personalities' values becoming in educational process, defines the methodology of pedagogical influencing by interactive teaching methods using psychotechnology, also describes the technology of personalities' values becoming. Using factor analysis, author traces directions values' changes in various groups of students by specialization, gender, and a researcher's influence. The training contributed to a significant activation of all intra-personal and socio-psychological effects and mechanisms of values becomingn. The conducted multivariate analysis of variance actually confirmed all the working hypotheses and concluded that the introduction of training in the educational process increases the influence of social and psychological mechanisms and promotes the intensification of intrinsic mechanisms of students' values becoming (reliable I-values). A significant increase in the rank of T-values of Development and Cognition was observed in all students who voluntarily participated in the experiment, and observed some differential effects resulting from the interaction of independent factors of gender and specialty. Significant changes that occurred in the values of students among the values-goals of "Development" and "Cognition", and among the values-means "Education" and "Sensibility" are the consequence that in the training process these values are maximized by the requirements for the subject educational activities.

\section{REFERENCES}

1.Бурлачук Л.Ф. Словарь-справочник по психодиагностике / Л.Ф. Бурлачук. С.М. Морозов - Киев : Наукова думка, 1989, p. 48.

2. Bendler R. Magic in actions / R. Bendler. Meta Publications, U.S.; New edition (1 Jun. 1992). 228 p.

3. Bolotov V.A. Development of Professional Pedagogical Education / V.A. Bolotov, V.I. Slobodchykov / Pedagogy. - 1997. - № 4. - Pp. 66-68. Hartmann N. Ethics / N. Hartmann. - M., 1958.

4. Hegel H.V.F. Philosophy of History / H.V.F. Hegel / Works M.-L., 1935. - T. 8. - Pp. 8-132.

5. Husserl E. Philosophy, as Strict Science / E. Husserl. - M.: Logos, 1911, vol. 1.

6. Johnson R. 1940 NLP Training Exercises. - Moscow: Publishing “+ PCB, 2001. - 384 p. 
7. Zymbardo F., M. Liayppe Social Impact / R. Johnson - Ed.: Peter, 2001. $-448 \mathrm{pp}$.

8. Leontyev D.A. Methods of Studying Value Orientations / D.A. Leontyev. - M.: Meaning, 1992. -64 p.

9. Parygin B.D. Fundamentals of Socio-Psychological Theory / B.D. Parygin. - M: Thought, 1971. Dictionary of Psychology - Moscow: Politizdat, 1990. - $494 \mathrm{p}$.

10. Romanyuk L.V. Psychology of personality values' becoming / L.V. Romanyuk. Manuscript. The thesis for obtaining of the Doctor's degree in psychological science, specialty 19.00.07. - Educational and Developmental Psychology. - Taras Shevchenko National University of Kyiv, Kyiv, 2014. - Pp. 57-70.

11. Revell J. In Your Hands. NLP in ELT / J. Revell, S. Norman. London: Saffire Press, 1997. - 144 p.

12. Rokeach M. Beliefs, Attitudes and Values / M. Rokeach. - San Francisco: Josey-Bass Co, 1972. - $214 \mathrm{p}$.

13. Rokeach M. The nature of human values / M. Rokeach. - New York : Free Press, 1973.

14. Romenets V.A. History of Psychology of the Twentieth Century / V.A. Romenets I.P. Manokha / Introduction by V.A. Tatenko, T.N. Titarenko. - K.: Lybid, 1998. - 992 p.

15. Reference Dictionary of Psychological Diagnosis / Burlachuk L.F., Morozov S.M.; Ed. in Chief Krymskiy S.B. - Kiev: Science. Dumka, 1989. $-200 \mathrm{p}$.

16. Self-realization and Prediction of Individual's Social Behavior / ed. V.A. Yadov. - L.: Nauka. Leningrad Branch, 1979. - 264 p. Usnadze D.N. Psychological Research / D.N. Usnadze. - M.: Nauka, 1969. $-213 \mathrm{p}$.

17. Yadov V.A. On Dispositional Regulation of Social Behavior of Individual / V.A. Yadov // Methodological problems of social psychology M.: Nauka 1975. - Pp. 89-105.

\section{Information about the author: Romanyuk L. V. Dr., Professor,}

V. I. Vernadsky Taurida National University 33, Ivana Kydri str., Kyiv, 01042, Ukraine 